\title{
Giant Penoscrotal Elephantiasis: A Case Report
}

\author{
Kimassoum Rimtebaye1", Mohamed Jalloh2, Arya Zarif Agah Tashkand1, \\ Franklin Danki Sillong3, Lamine Niang2, Serigne Magueye Gueye ${ }^{2}$ \\ ${ }^{1}$ Hôpital Général de Référence Nationale (HGRN) de N'Djaména, N'Djaména, Tchad \\ ${ }^{2}$ Hôpital Général de Grand Yoff (HOGGY) de Dakar, Dakar, Senegal \\ ${ }^{3}$ Hôpital Protestant de N'Gaoundéré, N'Gaoundéré, Cameroun \\ Email: ${ }^{*}$ melinarim@yahoo.fr
}

Received 26 June 2015; accepted 4 August 2015; published 7 August 2015

Copyright (C) 2015 by authors and Scientific Research Publishing Inc.

This work is licensed under the Creative Commons Attribution International License (CC BY).

http://creativecommons.org/licenses/by/4.0/

c) (i) Open Access

\begin{abstract}
Introduction: To present the histopathological, etiologic aspects and the surgical procedure to treat a penoscrotal elephantiasis. Observation: A 60-year-old patient was referred for a giant scrotum for 30 years. His general status was poor. The scrotum was bulky, posed a cosmetic problem and limited the patient mobility. He underwent a surgical treatment with removal of the mass. Pathology of the specimen was suggestive of either a non specific fibrosis or a benign vascular tumor. Conclusion: Giant scrotum is rare. The treatment is surgical.
\end{abstract}

\section{Keywords}

Cosmetic, Scrotum, Penoscrotal Elephantiasis, Fibrosis, Male Genital Neoplasms

\section{Introduction}

Penoscrotal elephantiasis is a rare disease entity and generally encountered in endemic filariasis areas [1]-[4]. According to the World Health Organization, more than a billion people are still at risk of endemic lymphatic filariasis in 80 countries. The main causative agent is Wuchereria bancrofti and the main vector is the Culex mosquito. Transmission to humans occurs in a sting [5]. Penoscrotal elephantiasis is usually caused by an extrinsic or intrinsic lymphatic obstruction. It poses etiologic, therapeutic, cosmetic and psychological problems.

The literature often emphasizes that elephantiasis in general and penoscrotal localization in particular are caused by filariasis. At the stage of the accrued damage, research of microfilariae is always negative.

The histology is essential to establish the diagnosis and refute a malignant tumor which is a real obsession in

${ }^{*}$ Corresponding author.

How to cite this paper: Rimtebaye, K., Jalloh, M., Zarif Agah Tashkand, A., Danki Sillong, F., Niang, L. and Gueye, S.M. (2015) Giant Penoscrotal Elephantiasis: A Case Report. Open Journal of Urology, 5, 109-113.

http://dx.doi.org/10.4236/oju.2015.58017 
such clinical presentation.

From an observation, the authors present the clinical and pathological aspects and report their surgical management.

\section{Observation}

A 65-years-old patient, without medical history presented a giant scrotum for 30 years. The scrotum had the size of a balloon of 10 liters capacity (Figure 1). The mass also involved the penis.

The mass was a reason for many referrals in health facilities and charlatans without improvement. At his admission his general status was poor, he was pale, dehydrated, with fatigue, depressive and could only move on a stroller. Physical examination revealed massive scrotum, irregularly shaped with columns and cells giving the appearance of a pachyderm skin. The tumor was so large it left its mark on the inner sides of the thighs. The mass was painless and so stony that the patient could seat on it. The skin covering the scrotum was keratinized, giving a striped appearance.

The skin could be unfolded showed the depth of the wrinkles that varied by location from $1 \mathrm{~cm}$ to $5 \mathrm{~cm}$.

The patient was immediately admitted. He underwent blood work including blood cell count, blood grouping, electrolytes, microfilaria research, blood glucose, creatinine, serology (chlamydia, syphilis and HIV). Serological tests and research of microfilaria were negative.

After correction of anemia and electrolyte disorders, the patient underwent surgery under spinal anesthesia. Excision of all the skin and pathological scrotal envelopes was performed. Testes were spared and underwent an orchidopexy, no procedure was done at that time on the penile indurations. A passive drainage was performed to the skin. The extirpated scrotal mass weighed $7.400 \mathrm{~kg}$. Pathological analysis (Figure 2 and Figure 3) of the specimen concomitantly carried out in 2 separated pathology departments from 2 countries reported different results: benign vascular tumor for one of them and nonspecific fibrosis for the other one. It is important to note that both laboratories found only benign lesions.

The postoperative course was uneventful. Removal of the drain was made on the seventh day. Scarring was effective in the $17^{\text {th }}$ day (Figure 4). There was no recurrence with a follow up of two years. Scrotum and penis recovered their softness and had a satisfactory appearance (Figure 5), sexual activities resumed.

\section{Discussion}

The literature typically links a large chronic painless scrotum to a greater abundance of hydrocele or a large inguinal scrotal hernia.

Our case involved a penoscrotal elephantiasis because the pachyderm interested both scrotum and penis. The volume and weight $(7.400 \mathrm{~kg})$ of the penoscrotal mass constituted a disability limiting patient walk and physical and sexual activity. Dekou A. et al. [6] characterized these large grants lymphangitis as huge mass with a hypertrophy of the external genitalia that disables and suspends all the patient activities including school and sports activities.

Examination of the patient noted the large volume of scrotum, pachydermia but also the presence of columns of cells such as haustrations never described in a publication. The striped appearance was however underlined by Dekou A. et al. [6].

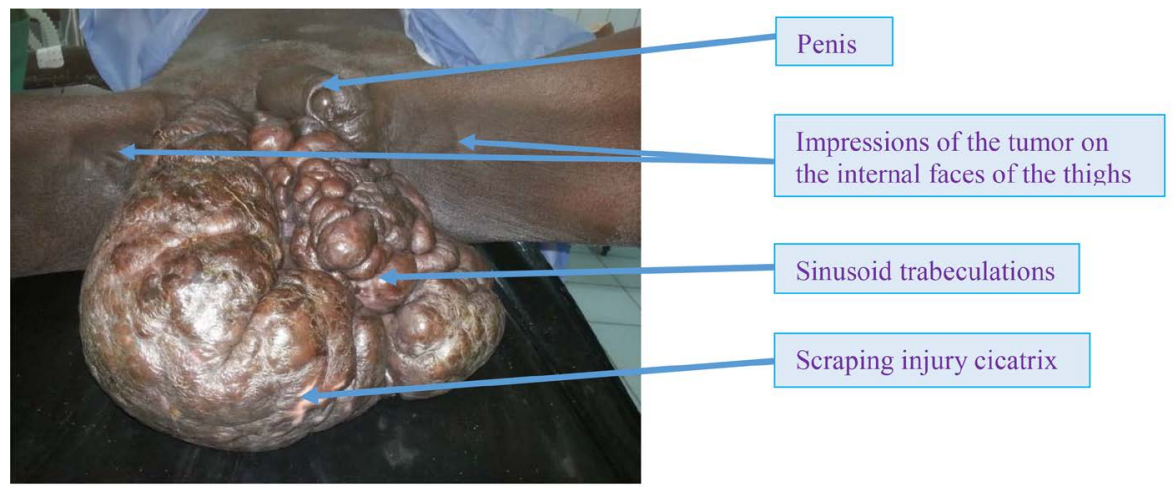

Figure 1. Penoscrotal tumor. 


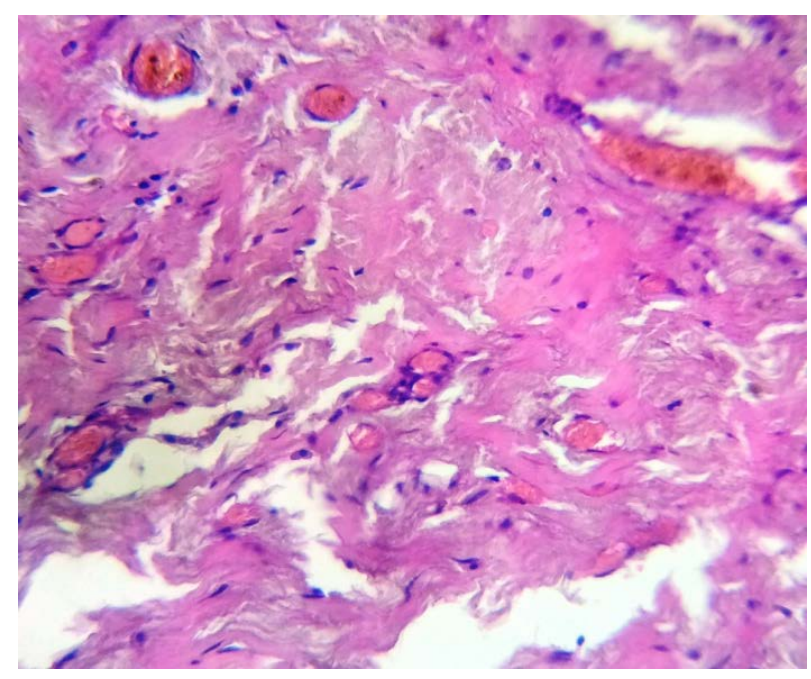

Figure 2. Histological image 1.

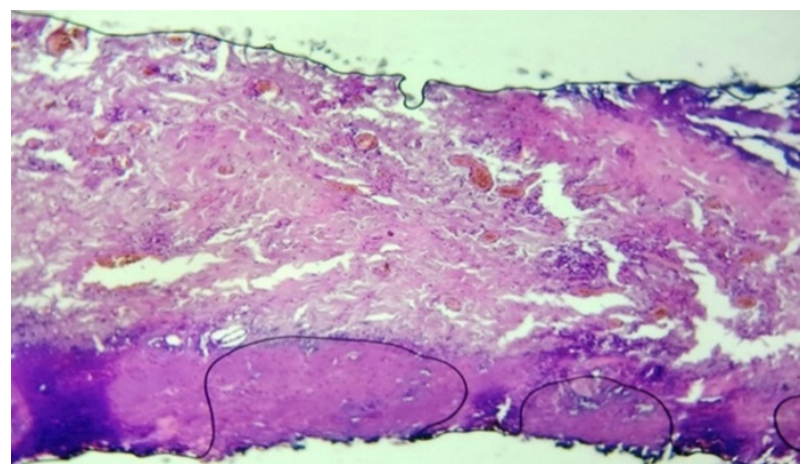

Figure 3. Histological image 2.

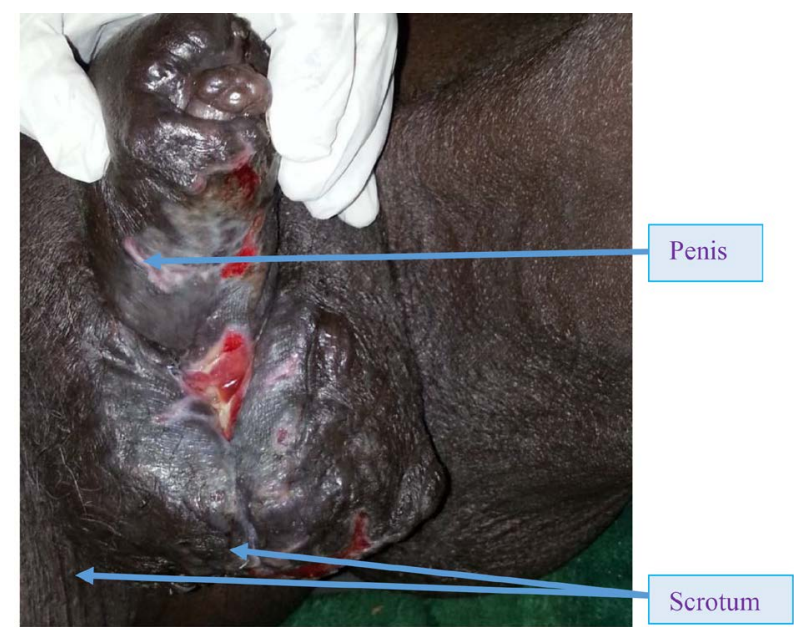

Figure 4. Aspect of the wound to J17.

Scrotal mass of the patient was so large that it ended up leaving its prints on the inner thighs like an internal concavity as if the tumor was digging a stall to settle in.

The volume and stony hardness of the scrotal mass justify its use as a set on which the patient has seated for years. For Slama A. et al. [3], the scrotal elephantiasis is variable in size and is covered with a thick skin that loses its elasticity. 


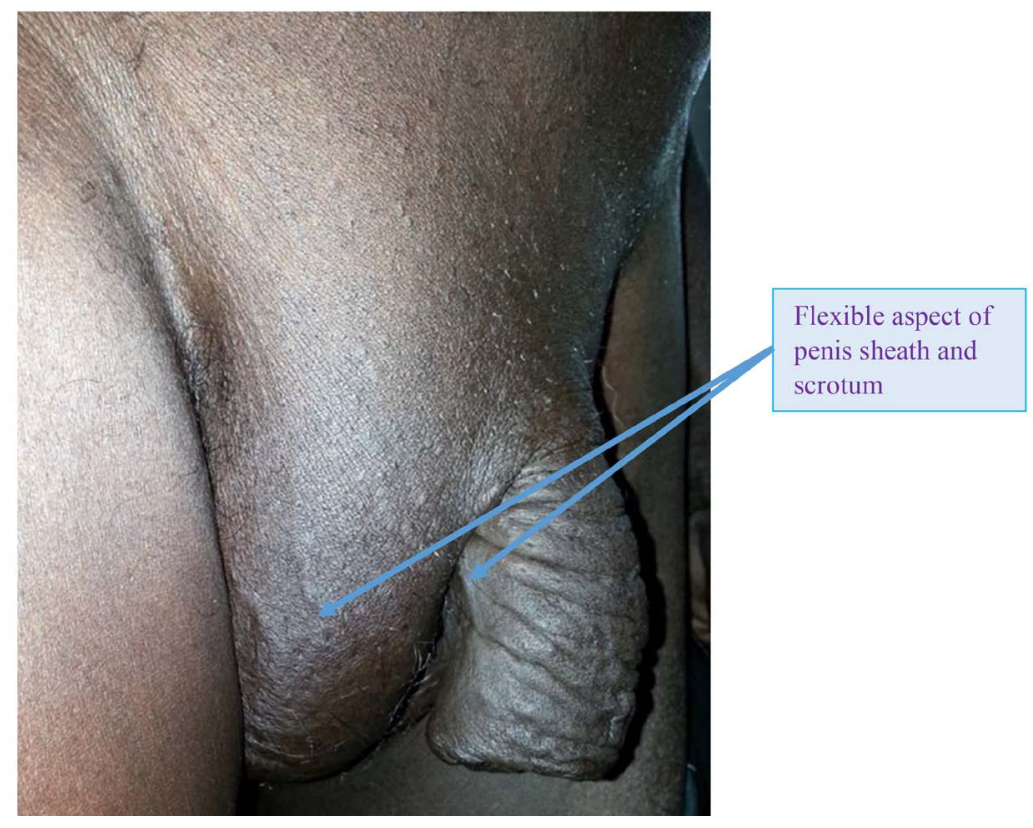

Figure 5. External genitalia aspects 2 years after scrotal plasty.

In these patients suffering from penoscrotal elephantiasis, the penis is often returned if not completely buried in the scrotum [3].

We hypothesized that the location of penile elephantiasis was due to the compression by the downward traction and the strangulation effect of the mass on the penis. This would explain the recovery of the penis (flexibility and elasticity) after excision of the scrotal mass without any action on the penis of our patient while several authors advised for a plasty of the penile skin [2] [3] [7] [8].

The pathology of the surgical specimen made by two different teams concluded to either non specific fibrosis or vascular tumor with no evidence of malignancy.

Note that in both cases the tumor was benign which contrast with the poor general status at admission that would be in favor of a malignancy. The fibrosis due to local compression reduced lymphatic drainage causing elephantiasis. The favorable evolution of surgical treatment was an argument in favor of the benignity of the lesion.

Penoscrotal elephantiasis treatment is surgical [5] [6] with varying surgical technics based on the volume of the mass and the experience of the surgeon. Our preference was focused on achieving total excision of the scrotal skin and envelopes overflowing onto healthy tissue followed by a bilateral orchidopexy and scrotal plasty. No surgery was performed on the penis. We estimated that passive drainage would avoid hematoma in the dead spaces and reduce blood loss compared to active drainage which would cause massive blood loss.

Penoscrotal elephantiasis is often idiopathic despite the prevalence of this pathology in the filarial endemic areas. At the stage of penoscrotal elephantiasis, the research of microfilaria is often negative [4]-[6].

Surgical excision has a cosmeticetic and diagnostic purposes.

If evolution is favorable for our patient, this is far from the rule because it can be punctuated by complications such as infection, lymphedema, subfertility...

\section{Conclusion}

Penoscrotal elephantiasis is a rare and idiopathic condition usually encountered in filarial endemic areas. Due to its weight and volume, physical and cosmetic characteristics the condition has psychological implications. It causes suspicions and doubt as to the possibility of malignancy. Pathology of the surgical specimen showed benign tissue. Filariasis often cited as etiology was unproven because the research of microfilaria was negative. Surgical treatment consisted of the removal of the scrotal mass with preservation of both testicles without penile plasty. The cosmetic and penis functional outcomes were good. 


\section{References}

[1] Coffman, J.D. and Eberhardt, R.T. (2003) Cutaneous Changes in Peripheral Vascular Disease. In: Freedberg, I.M., Eisen, A.Z., Wolff, K., Austen, K.F., Goldsmith, L.A. and Katz, S.I., Eds., Fitzpatrick's Dermatology in General Medecine, 6th Edition, McGraw-Hill Professional, New York, 1634-1650.

[2] Poornachandra, T., Shivananda, P., Alfred, J.A. and Shankar, R. (2012) Giant Scrotal Lymphoedema—A Case Report. International Journal of Surgery Case Reports, 3, 269-271. http://dx.doi.org/10.1016/j.ijscr.2012.03.005

[3] Slama, A., Jaidane, M., Elleuch, A., Sorba, N.B., Yacoubi, M.T. and Mosbah, A.F. (2002) Surgical Treatment of a Penoscrotal Elephantiasis. (Traitement chirurgical d’un éléphantiasis péno-scrotal). Progrès en Urologie, 12, 337-339.

[4] Tazi, M.F., Mellas, S., Ahallal, Y., Khallouk, A., El Fassi, M.J. and Farih, M.H. (2009) Penoscrotal Ephantiasis, Diagnosis and Management (about 3 Cases). (L’éléphantiasis pénoscrotal, diagnostic et prise en charge (à propos de 3 cas)). Andrologie, 19, 108-112. http://dx.doi.org/10.1007/s12610-009-0020-4

[5] Benatta, M., Boukerrouche, A. and Bazi, A. (2008) Penoscrotal Ephantiasis, a Case Report. (Eléphantiasis penoscrotal, à propos d'un cas). Journal de l'Association Marocaine d'Urologie, 9, 19-23

[6] Dekou, A., Konan, P.G., Yao, B., Vodi, C., Fofana, A. and Manzan, K. (2013) Idiopathic Penoscrotal Ephantiasis. A New Case and Review of the Literature. (Éléphantiasis pénoscrotal idiopathique: Une nouvelle observation et revue de la littérature). Canadian Urological Association Journal, 7, E29-E32.

[7] Nasehi, A. and Azadi, S.H. (2004) Elephantiasis of Penis and Scrotum. Urology Journal, 2, 55-57.

[8] Vaishampayan, S. (2008) Unusual Cause of Saxophone Penis. Indian Journal of Dermatology, venereology and Leprology, 74, 270-271. http://dx.doi.org/10.4103/0378-6323.41384 